\title{
Diet and trophic position of Leach's storm-petrel Oceanodroma leucorhoa during breeding and moult, inferred from stable isotope analysis of feathers
}

\author{
April Hedd*, William A. Montevecchi \\ Cognitive and Behavioural Ecology Programme, Departments of Psychology and Biology, \\ Memorial University of Newfoundland, St. John's, Newfoundland A1B 3X9, Canada
}

\begin{abstract}
We combined conventional dietary sampling (2002) with stable isotope analysis of nitrogen $\left(\delta^{15} \mathrm{~N}\right)$ and carbon $\left(\delta^{13} \mathrm{C}\right)$ in feathers of Leach's storm-petrels Oceanodroma leucorhoa (2001 and 2002) to investigate temporal, sex- and age-related variation in diet and trophic position, at Baccalieu Island, Newfoundland, Canada. Nestlings are fed mainly fish and crustaceans (ca. 90 and $9 \%$ by mass, respectively) toward the end of chick-rearing. The bulk of the fish were vertically migrating myctophids, associated with the offshore environment. Crustaceans were mainly parasitic hyperiid amphipods Hyperia galba, commonly found nearshore in association with scyphozoan jellyfish hosts. $\delta^{15} \mathrm{~N}$ values in summer-grown feathers were similar between years, but differed between age-classes in 2001 when chicks occupied slightly higher trophic level (3.2 vs. 3.1). $\delta^{13} \mathrm{C}$ values in summer-grown feathers were lower for chicks than adults. Predictions from a 3-source dual-isotope linear mixing model indicated that adults consumed $47 \%$ glacier lanternfish Benthosema glaciale, $5 \%$ capelin Mallotus villosis and $49 \%$ H. galba in 2001, while in 2002 respective values were 87,6 and $7 \%$. Model output for chicks was not biologically meaningful, possibly due to the lipid-rich (and $\delta^{13} \mathrm{C}$ depleted) stomach oil fed to chicks by adults. For adults, no sex differences were found in values of either isotope during summer. $\delta^{15} \mathrm{~N}$ values were significantly higher in feathers grown during summer than during mid-moult, suggesting increased consumption of crustaceans in winter. $\delta^{13} \mathrm{C}$ values in adult primaries were relatively enriched, consistent with movement of post-breeding birds toward tropical waters. Combining conventional and chemical analyses has provided some of the first insights into the year-round ecology of the smallest and most abundant seabird breeding in eastern North America.
\end{abstract}

KEY WORDS: Stable-isotopic analysis - Trophic level · Diet · Moult · Oceanodroma leucorhoa • Newfoundland $\cdot$ Storm-petrel

\section{INTRODUCTION}

The food and feeding ecology of seabirds in general, and Procellariiformes in particular, has been relatively well studied during summer when birds return to land to breed. In contrast, the non-breeding period that often extends well over half of the year is poorly studied as most species spend their time exclusively at sea. While archival and telemetric devices are revolutioniz- ing information on feeding ecologies - foraging and migratory strategies of larger species both during and outside breeding (e.g. Weimerskirch et al. 1993, 2002, Croxall et al. 2005, Garthe et al. 2006) — the lives of species too small to carry such devices remain relatively elusive.

Quantification of diets during breeding has traditionally been based on analysis of stomach content, but stable isotope analysis (SIA) of various tissues has also 
been used to estimate diet and trophic relationships for a variety of seabird communities (e.g. Hobson 1993, Hobson et al. 1994, Hodum \& Hobson 2000). SIA has also recently been used to identify foraging locations and therefore movements of birds between breeding and non-breeding seasons (e.g. Hobson 1999, Cherel et al. 2000, Quillfeldt et al. 2005). Isotope ratio variation in bird tissue reflects that in the local environment and is determined by the relative proportions of isotopically distinct dietary components (Hobson 1993). Feathers are an attractive tissue to sample because they can be collected non-destructively and feather keratin is metabolically inert after synthesis, so isotopic composition reflects diet at the time feathers were grown (e.g. Mizutani et al. 1992). For many procellariiform seabirds, breeding and moult are essentially exclusive in time, so determining the isotopic composition of feathers grown at different times of year represents a method of gathering information on temporal variation in feeding ecology (Cherel et al. 2000, Quillfeldt et al. 2005).

We investigated temporal, sex- and age- (adult vs. chick) related variation in the diet and trophic position of Leach's storm-petrel Oceanodroma leucorhoa at the center of its breeding range in the northwest Atlantic by combining conventional diet sampling with analyses of stable nitrogen and carbon isotope ratios in feathers of adults and chicks. Leach's storm-petrel is the smallest (ca.50 g) and most abundant seabird breeding in eastern North America. It is highly pelagic, feeding up to many hundreds of $\mathrm{km}$ from the colony, beyond the edge of the continental shelf (Brown 1986, G. K. Davoren et al. unpubl. data), and it feeds at the ocean surface. Adult-chick comparisons were made during the 2001 and 2002 breeding seasons using stable isotope values in feathers grown during the previous weeks at the breeding colony. Adult Leach's storm-petrels begin moulting tail feathers on the breeding grounds in August, some 4 to $6 \mathrm{wk}$ before chicks begin fledging (A. Hedd pers. obs.). During 2002, we also investigated chick diet using conventional sampling techniques. SIA was used to investigate relative changes in the trophic position of adults between breeding (summer) and moult (winter). Adults depart the colony after chicks fledge and are reported to winter in the tropics (Cramp \& Simmons 1977, Huntington et al. 1996). We contrasted adult tail feathers, grown on the breeding grounds, with a sequence of primary feathers (P1, P4, P7, P10) grown during the previous winter moult. Adult primary moult commences after birds depart the colony in fall and is complete before they return to breed the next season (Huntington et al. 1996). Combining conventional diet sampling with SIA allowed us to investigate temporal and age-related variation in diet and feeding ecology of Leach's storm-petrel through its annual cycle.

\section{MATERIALS AND METHODS}

Species, study site and field collections. This study was conducted in the Baccalieu Island Ecological Reserve $\left(48.12^{\circ} \mathrm{N}, 52.80^{\circ} \mathrm{W}\right)$, off the east coast of Newfoundland, Canada, where it is estimated that 3.5 million pairs of Leach's storm-petrels breed annually (Sklepkovych \& Montevecchi 1989). Within our study area, egg-laying begins late in May, the mean chick hatch date approximates late July and fledging begins mid-September (Huntington et al. 1996, A. Hedd unpubl. data). As part of another study (M. Logan unpubl. data), 10 adult-chick pairs (11 adults and 10 chicks) of Leach's storm-petrels were collected during late chick-rearing (early September) 2001, and a further 15 pairs (16 adults and 15 chicks) were collected in early September 2002 (Canadian Wildlife Service Scientific Take Permits SC2207 and SC2249). Birds were frozen in the field and maintained at $-20^{\circ} \mathrm{C}$ with the exception of brief thaws for tissue extraction, feather sampling and gender determination via dissection (adults only).

We obtained feather samples from these carcasses. Adults moult their tail and primary feathers annually (Cramp \& Simmons 1977). Tail moult begins late in the breeding season, while primary moult occurs solely outside the breeding period (Ainley et al. 1976, Cramp \& Simmons 1977). Primary moult is descendant, beginning October-November when birds may still be near the breeding grounds, and continuing during migration and on the tropical wintering grounds (Ainley et al. 1976, Cramp \& Simmons 1977, Hémery \& Jouanin 1988). Precise timing of primary moult is unknown but it is relatively protracted. Hémery \& Jouanin (1988) reported that all Age 1+ birds recovered during a midDecember wreck in the Bay of Biscay were moulting primary feathers. The outer 1 to 3 feathers were well worn (old), the next 1 to 2 were falling out or growing, while the remaining inner feathers had already been replaced. Primary moult is completed before the start of the next breeding season. In each year, we consequently sampled adult tail feathers grown at the breeding colony (2001 and 2002) and a sequence of primary feathers (from the right wing) grown at the beginning (P1), middle (P4, P7) or end (P10) of the 2000 or 2001 winter moult. For 6 adults (1 in 2001 and 5 in 2002) we used growing body feathers as opposed to tail feathers for the breeding season sample as these birds had just commenced tail moult and the tail feathers did not yield adequate material. For each chick, we sampled the tip of the most recently grown primary on the right wing. For the majority of chicks this was P10, but lower primaries were used for younger chicks. We also obtained specimens of 2 of the main prey types (myctophid or lanternfishes and Hyperiid amphipods) 
delivered to Leach's storm-petrel chicks in Newfoundland colonies (authors' unpubl. data). The glacier lanternfish Benthosema glaciale were collected on board CCGS 'Teleost' during standard capelin Mallotus villosus tows (using $12 \mathrm{~mm}$ mesh nets) in May 2002, while jellyfish Aurelia aurita and Cyanea capillata were collected with pole nets from a small vessel outside St. John's harbour, Newfoundland, in September 2002. Hyperiid amphipods Hyperia galba were removed from the jellyfish gonads. Prey samples fell within the size range consumed by Leach's stormpetrels, and they were stored frozen until analysis.

Between 31 August and 1 September 2002, 49 diet samples were collected from adults caught in mist-nets at night. Plastic tarps laid under nets facilitated sample recovery as many birds spontaneously regurgitated stomach contents either upon impact with or when being removed from the net. Birds were subsequently inverted and their stomachs gently massaged to obtain any food that remained in the gut. Samples were placed in individual bags and frozen. In the laboratory, samples were thawed, and weighed before and after draining to estimate the mass contribution of liquid and solid material. Solid material was subsequently washed through a series of stacked sieves, placed in a sorting tray and separated into broad prey classes (fish, cephalopods, crustaceans, others). Each prey class was weighed to estimate the fresh mass contribution. Within each class, individual prey were identified to the lowest possible taxon and counted. Samples were generally well digested, and all fish were identified from otoliths using Härkönen (1986), Campana (2004) and material held at the Department of Fisheries and Oceans in St. John's. Crustaceans were identified following Dunbar (1963). Otoliths were paired, counted separately left and right and the number of fish was estimated from the larger count. When fish was noted from flesh or bones alone, we assumed it represented 1 individual. Total length of intact amphipods and euphausiids was measured, under a dissecting microscope fitted with a graticule, from the front of the eye to the tip of the uropods and from the tip of the rostrum to the tip of the uropods, respectively. Body length of fish was estimated from uneroded otolith dimensions using either published relationships (Härkönen 1986, Winters 1989, Olsson \& North 1997) or our own equations. To reconstruct the mass composition of the diet, the body masses of crustaceans and fish were estimated from lengths using either published relationships (Härkönen 1986), or our own equations. Speciesspecific equations were used where possible, but when not available, estimates were made from closely related species or from species with similar morphology. The reconstructed mass of each species/taxon was calculated by multiplying average body mass by the number of individuals recovered. The calculated mass for all taxa was pooled and expressed as a percentage of the total. In total, $41 \%$ of fish (52 of 128) were unidentified and to conduct the mass reconstruction, we assumed that these fish were distributed (by number) in the same relative proportion as those we identified. Data are presented as percent frequency of occurrence, number and reconstructed mass.

Tissue preparation, stable isotope measurements and models. Feathers were placed in glass scintillation vials and cleaned of surface contaminants using a 2:1 ratio solution of chloroform:methanol. Feathers were air dried for $24 \mathrm{~h}$ and cut into small fragments using stainless steel scissors. We avoided the quill and shaft. For fish, a piece of muscle was removed from each thawed specimen, while a number of whole amphipods $(\geq 10)$ were combined to create a single sample. Prey samples were oven dried to constant mass at $+60^{\circ} \mathrm{C}$, coarsely ground and lipids were removed using a 2:1 ratio solution of chloroform:methanol. Amphipods were additionally placed in $1 \mathrm{~N} \mathrm{HCl}$ to remove carbonates (for ca. $1 \mathrm{~h}$ ), and then rinsed with distilled water (for ca. 2 h). Prey samples were then ground to a fine powder using a mortar and pestle. From each feather and prey sample, a $1 \mathrm{mg}$ subsample was weighed into a tin cup that was crushed into a pellet and saved for isotopic analysis. All instruments were cleaned with acetone between samples to prevent cross-contamination. Samples were sent to David Harris at the Stable Isotope Facility, University of California, Davis, USA, for determination of isotope values.

Stable isotope values are expressed in delta notation $(\delta)$ as parts per thousand (\%) according to the following:

$$
\delta X=\left[\left(R_{\text {sample }} / R_{\text {standard }}\right)-1\right] \times 1000
$$

where $X$ is ${ }^{15} \mathrm{~N}$ or ${ }^{13} \mathrm{C}$ and $R$ is the corresponding ratio ${ }^{15} \mathrm{~N} /{ }^{14} \mathrm{~N}$ or ${ }^{13} \mathrm{C} /{ }^{12} \mathrm{C}$. $R_{\text {standard }}$ for ${ }^{15} \mathrm{~N}$ and ${ }^{13} \mathrm{C}$ are atmospheric $\mathrm{N}_{2}$ (AIR) and the PeeDee Belemnite (PDB) standard, respectively. Replicate measurement of laboratory standards (2 standards for every 12 unknowns) indicated measurement errors of approximately 0.2 and $0.1 \%$ for nitrogen and carbon, respectively.

While carbon is not generally used to indicate trophic position (Hobson \& Welch 1992), we simultaneously determined carbon and nitrogen in our samples. Two isotopes are superior at segregating species and presumably distinguishing temporal differences within a species, and stable carbon isotope ratios have previously been used to infer inshore or benthic vs. offshore or pelagic feeding in seabirds (e.g. Hobson et al. 1994). Isotope values of food fractionate or change when incorporated into consumer tissues according to the following:

$$
D_{\mathrm{t}}=D_{\mathrm{d}}+\Delta_{\mathrm{dt}}
$$


where $D_{\mathrm{t}}$ is isotopic value in the tissue, $D_{\mathrm{d}}$ is isotopic value in the diet, and $\Delta_{\mathrm{dt}}$ is isotopic fractionation factor between tissue and diet. Cherel et al. (2005) reviewed all control studies and reported average discrimination factors between lipid-extracted whole prey and feathers for fish-eating birds at $+4.2 \pm 0.7 \%$ o $(\mathrm{n}=12)$ for $\delta^{15} \mathrm{~N}$ and $+1.2 \pm 1.2 \%$ o $(\mathrm{n}=6)$ for $\delta^{13} \mathrm{C}$, and we adopted their values. Stable nitrogen and stable carbon values of fish (herring Clupea harengus and capelin) were also found to differ depending on whether they derived from muscle tissue or whole specimens (Cherel et al. 2005), with whole fish being depleted in $\delta^{15} \mathrm{~N}$ by $-0.9 \pm 0.1 \%$ and enriched in $\delta^{13} \mathrm{C}$ by $+0.3 \pm 0.1 \%$. As both our values for fish and those from the literature (Sherwood \& Rose 2005) were derived from muscle, they were appropriately adjusted prior to applying models to estimate dietary contributions. We used the 3-source dualisotope mixing model (Phillips \& Gregg 2001) which provides standard errors and confidence intervals for source proportion estimates, accounting for the variability observed in sources (prey species) as well as the mixture (feathers). The main prey of chick-rearing Leach's storm-petrel in Newfoundland are myctophid fishes (represented by the glacier lanternfish) and hyperiid amphipods Hyperia galba (authors' unpubl. data), with capelin making a contribution at some sites in some years. We estimate that lanternfishes, hyperiid amphipods and capelin together constituted $87 \%$ of chick diet at Baccalieu in 2002.

To calculate the trophic level (TL) of a consumer $\left(\mathrm{TL}_{\text {consumer }}\right)$, we used the mean TL for pelagic zooplankton on the Newfoundland and Labrador continental shelf (2.1; Sherwood \& Rose 2005) and an isotopic enrichment factor between TLs of $3.6 \%$, calculated by Fry (1988) for the George's Bank region. The TL in the food web may be calculated as:

$\mathrm{TL}_{\text {consumer }}=2.1+\left(D_{\text {consumer }}-D_{\text {pelagic zooplankton }}\right) / 3.6$

where $D_{\text {consumer }}$ is the isotopic signature of the consumer and $D_{\text {pelagic zooplankton }}$ is that for pelagic zooplankton $(9.9 \%$, Sherwood \& Rose 2005$)$.

Effects of age (adult vs. chick) and sex on isotope values in feathers grown during the breeding period, and interactions between factors, were tested with 1- or 2- way ANOVA, as appropriate. Effects of year, sex, and time of collection on isotope values in adult feathers, and interactions between factors, were tested using repeated measures ANOVA with the Wilk's Lambda statistic. When significant differences $(p<0.05)$ were found, pairwise comparisons were conducted without correction for multiple comparisons. All tests except Levene's test for equal variance (Minitab release 13.30) were conducted using Systat for Windows (v10.2). Values are presented as means $\pm 1 \mathrm{SD}$.

\section{RESULTS}

\section{Stable isotope analysis}

$\delta^{15} \mathrm{~N}$ values ranged from $8.9 \pm 0.5 \%$ in Hyperia galba to $14.0 \pm 0.4 \%$ in feathers of Leach's storm-petrel chicks in 2001 (Tables $1 \& 2$, Fig. 1). $\delta^{13} \mathrm{C}$ values ranged from $-20.7 \pm 0.6 \%$ in $H$. galba to $-17.4 \pm 0.4 \%$ in adult primary feathers (P10) grown in the 2000/01 inter- 
breeding (moulting) period. During the breeding season, feather $\delta^{15} \mathrm{~N}$ values were similar between years for adults (2-way ANOVA, $F_{1,23}=0.68, \mathrm{p}=0.42$ ) and for chicks $\left(F_{1,23}=1.78, \mathrm{p}=0.20\right)$, but differed between age classes in 2001 when values for chicks were higher $\left(F_{1,19}=10.22, \mathrm{p}=0.005\right)$. In $2002, \delta^{15} \mathrm{~N}$ values were similar for adults and chicks $\left(F_{1,29}=0.01, \mathrm{p}=0.92\right) . \delta^{13} \mathrm{C}$ values were similar between years for chicks $\left(F_{1,23}=\right.$ $3.09, \mathrm{p}=0.092)$, whereas for adults, values were significantly higher in 2002 (2-way ANOVA $F_{1,23}=8.27, \mathrm{p}=$ 0.009). $\delta^{13} \mathrm{C}$ values differed between these age-classes, being significantly higher in adult than in chick feathers in $2002\left(F_{1,29}=53.37, \mathrm{p}<0.001\right)$; a non-significant trend that was also observed in $2001\left(F_{1,19}=3.94, \mathrm{p}=\right.$ 0.062). There were no significant sex effects or sex by year interactions for values of either isotope in adult feathers grown during the breeding season.

$\delta^{15} \mathrm{~N}$ values varied significantly among adult primary feathers (2-way repeated measures ANOVA, Wilk's Lambda $F_{3,21}=5.12, \mathrm{p}=0.008$ ), with those for P4 and P7 (grown during mid-moult), being significantly lower than for P1, which is the first flight feather to be renewed $(p<0.05)$. There were no effects of sex or year on $\delta^{15} \mathrm{~N}$ values in these feathers. For $\delta^{13} \mathrm{C}$, there was significant between-year variation (2-way repeated measures ANOVA, Wilk's Lambda $F_{1,23}=6.79, \mathrm{p}=0.016$ ), so the years were examined separately. In $2001, \delta^{13} \mathrm{C}$ values varied significantly among adult primary feathers (repeated measures ANOVA, Wilk's Lambda $F_{3,8}=6.73, \mathrm{p}=0.014$ ), being significantly greater in P10 than in P1, P4 or P7 $(\mathrm{p}<0.05) . \delta^{13} \mathrm{C}$ values were similar in all primary feathers grown during the 2001/02 moult (repeated measures ANOVA, Wilk's Lambda $F_{3,13}=0.55, \mathrm{p}=0.660$ ).

For adults, we also contrasted feathers grown in summer and winter. $\delta^{15} \mathrm{~N}$ values varied significantly (2-way repeated measures ANOVA, Wilk's Lambda $F_{4,20}=9.98, p<0.001$ ), and were higher in feathers grown at the colony in summer than in those grown during mid-moult in winter ( $\mathrm{P} 4$ and $\mathrm{P} 7$; $\mathrm{p}<0.01)$. This tendency was also observed for the final primary (P10), but the result was marginally non-significant $(\mathrm{p}=0.051)$. In both years, $\delta^{13} \mathrm{C}$ values were significantly different between breeding and moult (repeated measures ANOVA, Wilk's Lambda, for $2001 F_{4,7}=7.81, \mathrm{p}=0.10$, and for 2002
$F_{4,12}=4.98, \mathrm{p}=0.013$ ), and in both years, values in feathers grown on the breeding grounds were significantly lower than in all feathers grown during winter ( $p<0.05$ for all).

We used variance in $\delta^{15} \mathrm{~N}$ data as a proxy for dietary breadth (Hodum \& Hobson 2000), and examined the relative degree of individual variability during breeding and moult. Mean $\delta^{15} \mathrm{~N}$ variance across years for adults during breeding $(0.36 \pm 0.29 \%)$ was significantly lower than observed during moult (Levene's test $=10.31, \mathrm{p}<0.01 ; \mathrm{P} 1=0.66 \pm 0.24 \%$ o, $\mathrm{P} 4=1.21 \pm$ $0.16 \%$, P7 $=1.14 \pm 0.31 \%, \mathrm{P} 10=1.55 \pm 0.05 \%$ o). Chick dietary breadth was also relatively low $(0.37 \pm 0.22 \%)$ and showed similar variability to that of adults (Levene's test $=0.66, \mathrm{p}=0.42$ ).

\section{Food samples}

Food samples $(\mathrm{n}=49)$ collected from adult stormpetrels returning to Baccalieu Island, Newfoundland, on 31 August to 1 September 2002 averaged $5.2 \pm 2.5 \mathrm{~g}$

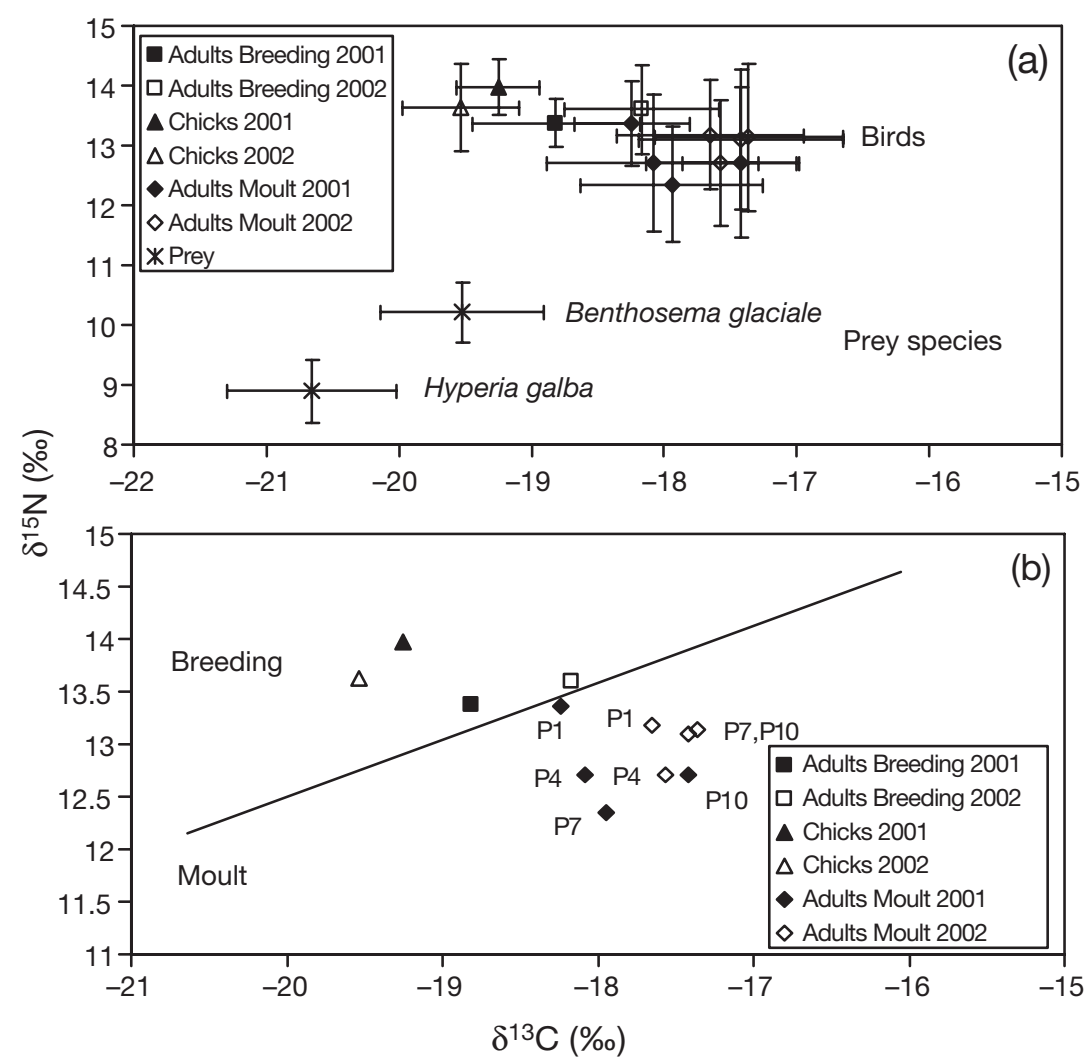

Fig. 1. Oceanodroma leucorhoa. Mean $( \pm \mathrm{SD}) \delta^{15} \mathrm{~N}$ and carbon $\delta^{13} \mathrm{C}$ values of (a) Leach's storm-petrels and their prey in 2001 and 2002. (b) Values for bird only measurements (error bars omitted for clarity). Diagonal line separates the breeding and moulting periods. For adults, moutling samples consist of primary feathers grown at the beginning (P1), middle (P4, P7) or end (P10) of winter 
(range 0.3 to $10.9 \mathrm{~g}$ ). By mass, these samples were $57 \%$ solid and $43 \%$ liquid. The solid portion ( $\mathrm{n}=48)$ was composed of $80.3 \%$ fish, $19.7 \%$ crustacean and $<0.1 \%$ cephalopod. Fish dominated (i.e. $>50 \%$ by fresh mass) in 43 of the samples, while crustaceans dominated in 5 samples.

Chick food was dominated by fish, which accounted for $90.0 \%$ by reconstructed mass (Table 3). Crustaceans were the only other important prey class, accounting for $9.2 \%$ of diet mass, while remains of a single squid contributed the rest $(0.7 \%)$. A total of 2264 prey were recovered, including 2136 (94.3\%) crustaceans, 128 (5.7\%) fishes and $1(<0.1 \%)$ cephalopod. The fish component of the diet was generally well digested, being dominated by offshore species from the family Myctophidae (66 of 76 identified fish). As only $59 \%$ (76 of 128 ) of fish could be identified, $37 \%$ of the overall diet mass was placed in an unidentified/ digested fish category (Table 3). Myctophids ac counted for $77 \%$ of the mass of identified fish (41.2 of $53.4 \%$; Table 3 ) and sexually mature individuals of 2 species were important: the glacier lanternfish and Arctic telescope Protomyctophum arcticum. Three spotted lanternfish Myctophum punctatum were also recovered. Capelin and sand lance Ammodytes spp. were also important to storm-petrel chicks in 2002, contributing 6.6 and $3.7 \%$ by mass, respectively. Capelin and sandlance each occurred in just $6 \%$ of samples, but the large size of capelin in particular (7.5 g) resulted in its significant mass contribution. The

Table 3. Oceanodroma leucorhoa. Chick diet of Leach's storm-petrel $(\mathrm{n}=49)$ at Baccalieu Island, Newfoundland, 31 August to 1 September 2002. \% RM: reconstructed mass

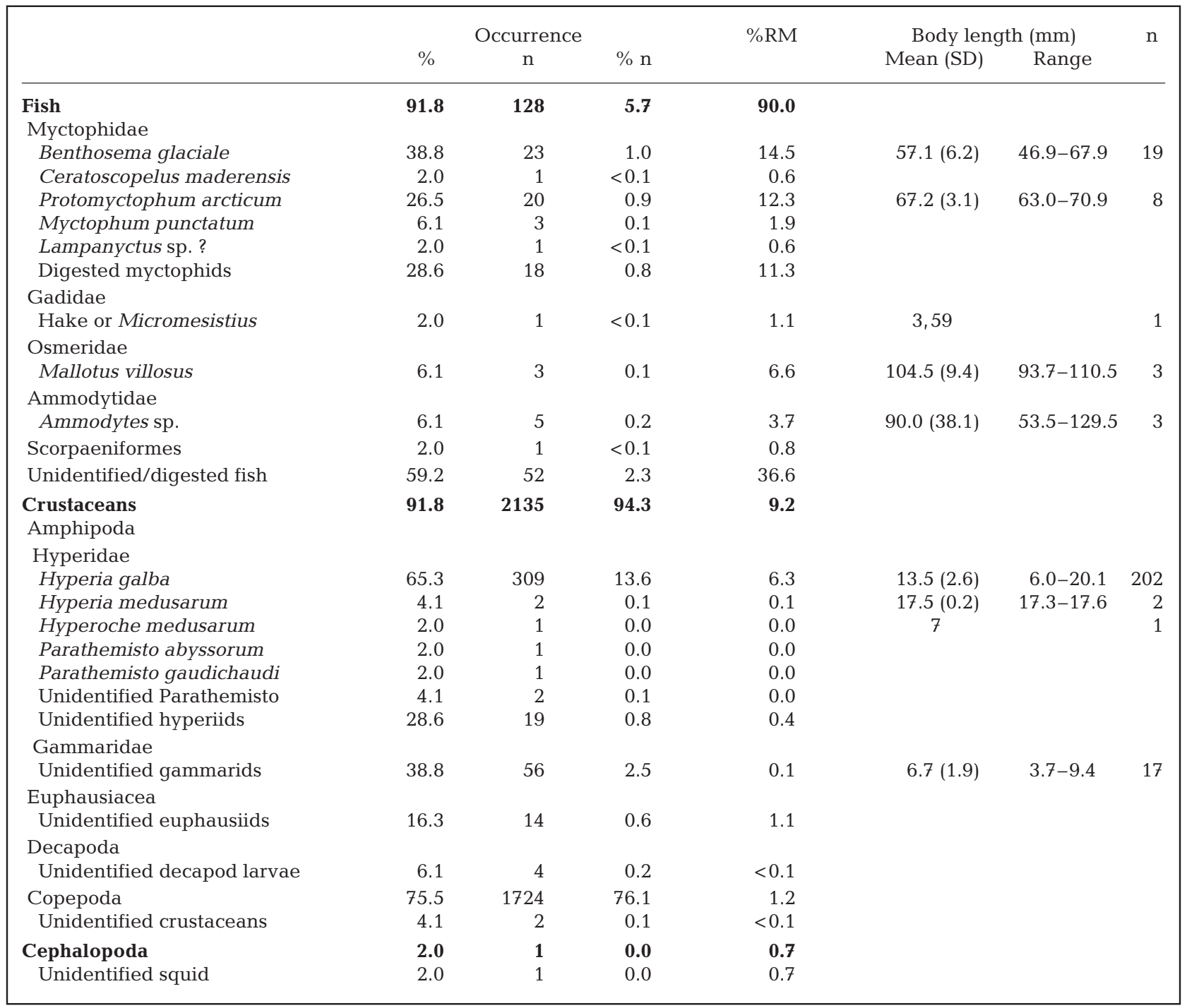


Table 4. Oceanodroma leucorhoa. Estimates of the diet composition of Leach's storm-petrel using the 3 source (glacier lanternfish, capelin, hyperiid amphipod), dual isotope $\left(\delta^{15} \mathrm{~N}, \delta^{13} \mathrm{C}\right)$ linear mixing model described by Phillips \& Gregg (2001). Data given as mean \pm SE (95\% confidence interval)

\begin{tabular}{|ccccc|}
\hline & $\mathrm{n}$ & $\begin{array}{c}\text { \% glacier } \\
\text { lanternfish }\end{array}$ & \% capelin & $\begin{array}{c}\text { \% Hyperiid } \\
\text { amphipod }\end{array}$ \\
\hline Adults & & & & \\
2001 & 11 & $47 \pm 15(15-78)$ & $5 \pm 7(0-20)$ & $49 \pm 14(19-78)$ \\
2002 & 16 & $87 \pm 15(56-100)$ & $6 \pm 10(0-26)$ & $7 \pm 15(0-38)$ \\
Chicks & & & & \\
2001 & 10 & $13 \pm 10(0-35)$ & $35 \pm 8(18-52)$ & $51 \pm 11(28-75)$ \\
2002 & 15 & $0 \pm 13(0-29)$ & $21 \pm 10(1-41)$ & $79 \pm 15(49-100)$ \\
& & & & \\
\hline
\end{tabular}

groups suggested both age-related (adult vs. chick) and time of year effects on diet composition and TL, with adults elevating TL during chick rearing and delivering mainly fish to their offspring. Stable carbon isotope values varied among the groups of feathers examined for adult birds, possibly reflecting the latitudinal gradient in $\delta^{13} \mathrm{C}$ (e.g. Rau et al. 1982, Goericke \& Fry 1994) as birds shift foraging grounds between breeding and moult (Huntington et al. 1996). Combining conventional and stable isotope approaches has enabled adult-chick TL

hyperiid amphipod Hyperia galba was the most important crustacean in the diet, occurring in $65 \%$ of samples and accounting for $6.3 \%$ of diet mass. Copepods occurred in $75 \%$ of samples but these and euphausiid crustaceans each contributed just only ca. $1 \%$ by mass. Unidentified gammarids occurred in $39 \%$ of samples, but were also a minor $(<0.1 \%)$ mass component.

\section{Isotope model estimates of adult and chick diet during breeding}

Using isotopic signatures of feathers (corrected), whole fish (Benthosema glaciale, capelin) and amphipods (Hyperia galba), we obtained estimates of adult and chick diet from the dual isotope model $\left(\delta^{15} \mathrm{~N}, \delta^{13} \mathrm{C}\right)$ of Phillips \& Gregg (2001; see Table 4). Toward the end of chick rearing in 2001, we estimate that adult diet consisted of $47 \%$ glacier lanternfish, $5 \%$ capelin and $49 \%$ hyperiid amphipods. Isotope values suggested that in 2002, adults consumed substantially more lanternfish (87\%) and less hyperiids (7\%), while the contribution of capelin to their diet was similar between years. Adult diet estimated from feather isotope values in 2002 closely resembled that collected via regurgitation that year. Model output for chick diets, however, poorly matched these regurgitations. While $77 \%$ of the mass of identified fish in regurgitations were myctophids, feather isotope values suggested that these fish were absent and the chick diet instead consisted of $21 \%$ capelin and $79 \%$ hyperiid amphipods. Possible reasons for this discrepancy are discussed below.

\section{DISCUSSION}

For Leach's storm-petrels breeding at Baccalieu Island in the Northwest Atlantic, we report a typical stepwise trophic enrichment of $\delta^{15} \mathrm{~N}$ from amphipods to seabirds. Variation in $\delta^{15} \mathrm{~N}$ values among feather comparisons and resulted in some of the first insights into the year-round ecology of Leach's storm-petrel, the smallest and most abundant seabird breeding in eastern North America.

\section{Diet composition and trophic level of Leach's storm-petrels during breeding}

As is typical for seabirds, the few dietary studies for Leach's storm-petrel have been conducted during chick rearing when adults return to the colonies with partially digested fish and a mix of crustacean prey for their chicks (Linton 1978, Watanuki 1985, Vermeer \& DeVito 1988, Montevecchi et al. 1992). Our results from conventional sampling at Baccalieu late in the 2002 chick-rearing period were consistent with fish, largely myctophids but also capelin and sand lance, comprising the bulk of chick diet, and hyperiid amphipods contributing the remainder. Leach's storm-petrel is highly pelagic during the summer breeding season, feeding up to many hundreds of $\mathrm{km}$ from the colony to beyond the edge of the continental shelf (Brown 1986, G. K. Davoren et al. unpubl. data). These distributional patterns are consistent with the myctophid-dominated prey delivered by adults to their chicks. Myctophids or lanternfishes are widespread mesopelagic fish predominantly found in open oceanic waters but also occurring over continental slopes and continental and island shelves (Nafpaktitis et al. 1977). During the day, myctophids occur at 300 to $1200 \mathrm{~m}$, while at night many migrate vertically to feed (Scott \& Scott 1988), presumably then becoming available to storm-petrels that feed at the surface. The glacier lanternfish is the most common myctophid north of $40^{\circ} \mathrm{N}$ in the Northwest Atlantic (Scott \& Scott 1988), and it comprised $95 \%$ of all myctophids collected in the Newfoundland Basin (McKelvie 1985).

Relative to the offshore distribution and temporally restricted (i.e. nocturnal) availability of myctophid 
fishes, Hyperia galba is more locally, if seasonally, available to breeding storm-petrels. $H$. galba is a shallow water, parasitic amphipod distributed in Arctic waters in association with large medusae of scyphozoan jellyfish hosts (largely Aurelia and Cyanea; Dahl 1959, Dittrich 1988). Both Aurelia and Cyanea occur off the Atlantic coast of Newfoundland (Shih 1977), where H. galba is common in fall (Frost 1936). Many amphipods delivered to storm-petrel chicks are intact, sometimes still alive, and are presumably caught close to colonies. In the Gulf of Maine, host jellyfish are common nearshore during summer and fall, seldom being found more than several $\mathrm{km}$ from shore (Bigelow 1926). Though highly seasonal (Dittrich 1988), H. galba represents a locally available meal for foraging stormpetrels or a 'top-up' for meals of fish collected further afield. Preying on both nearshore crustaceans and offshore fish suggests that Leach's storm-petrels have access to prey conditions that could facilitate a dual short and long foraging trip strategy as found in other procellarids (e.g. Weimerskirch et al. 1994).

Assuming that food loads collected from adults returning to colonies represent meals intended for chicks, there was a surprising lack of correspondence between isotopic and conventional determinations of chick diet in 2002. Model estimates of chick diets were not biologically meaningful because $\delta^{13} \mathrm{C}$ values in their feathers were lower than expected for a diet dominated largely by myctophid fishes. $\delta^{15} \mathrm{~N}$ values, however, were within the expected range, and largely similar to those obtained contemporaneously from adult feathers (Table 1). One possible explanation for this discrepancy involves the stomach oil adults feed to chicks, which in 2002 amounted to $43 \%$ of chick diet mass. Stable isotope methods trace protein pathways and generally provide little insight into sources of dietary lipids. However, Thompson et al. (2000) proposed that incorporating dietary lipids such as stomach oil (that are relatively depleted in ${ }^{13} \mathrm{C}$ ) into protein could provide an explanation for the relatively low $\delta^{13} \mathrm{C}$ values observed in procellariiformes, in general. While this hypothesis remains to be tested experimentally, it provides a potential explanation for our results if storm-petrel adults and chicks differentially rely on stomach oil as an energy source. We recommend measuring stomach oil isotopically in future studies to investigate this possibility.

Focusing on $\delta^{15} \mathrm{~N}$ values in feathers, we assessed potential TL separation of adults and chicks and also of adult males and females during breeding, assessments that were simply not possible using conventional sampling techniques. To conduct these comparisons, we assumed similar diet-feather fractionation values for adults and chicks, as a review of data for a variety of animal species (Hodum \& Hobson 2000) failed to find systematic age-related variation. Adult Leach's stormpetrels occupied TL 3.1 in both years (Table 1), equivalent to chicks in 2002 but statistically lower in 2001 when the chick food presumably contained more or higher TL fish. Hodum \& Hobson (2000) found significant age-related trophic segregation for 4 Antarctic fulmarine petrel species, with chicks occupying higher trophic positions than adults (TLs were 0.25 to 0.5 higher). Hobson (1993) also found that thick-billed murre Uria lomvia and black-legged kittiwake Rissa tridactyla chicks in Lancaster Sound, Canada, occupied higher trophic positions than adults, but found no similar separation for northern fulmars Fulmarus glacialis or glaucous gulls Larus hyperboreus. At least for Leach's storm-petrels in Newfoundland, selectively provisioning chicks with fatty myctophid fishes would facilitate rapid growth, as these fish have higher caloric content than amphipods. Adult-chick dietary differences might also be expected if adults spatially and/or temporally segregate provisioning for themselves and their offspring (Weimerskirch \& Cherel 1998, Davoren \& Burger 1999, Connan et al. 2005). Our data suggest that adults feed both themselves and their chicks a high proportion of fish during chick rearing, but there may be annual differences in the degree to which parental and offspring diets differ.

We found no significant sex differences in values of either isotope, suggesting that during the chick-rearing period adult males and females feed at a similar TL and use a similar range of foraging locations. For some procellariiform species (e.g. wandering albatrosses Diomedea exulans and giant petrels Macronectes spp.) substantial sex differences have been reported for both foraging location and the prey species selected for offspring provisioning (Weimerskirch et al. 1993, 1997, Gonzales-Solis et al. 2000, 2002). For these species sex differences have been attributed to the degree of dimorphism which is substantial particularly for the giant petrels. Leach's storm-petrels are largely monomorphic (Huntington et al. 1996), and therefore similar feeding ecologies for males and females are not unexpected.

\section{Feeding ecology over winter: trophic levels and foraging areas}

For Leach's storm-petrel, like many other procellariiform seabirds, breeding and moult of the primary feathers are temporally separated to avoid competing needs for energy and nutrients (Ainley et al. 1974, Huntington et al. 1996). Adult TL was significantly elevated ( 0.25 to 33 higher) during chick-rearing relative to moult when their diet likely consisted of a significant proportion of crustaceans. Adults also fed 
upon a wider range of species and occupied a correspondingly wider range of TLs in winter $\left(\delta^{15} \mathrm{~N}\right.$ values ranged 9.9 to $15.7 \%$, representing TLs 2.1 to 3.7 ) relative to during the breeding period when their dietary breadth was lower $\left(\delta^{15} \mathrm{~N}\right.$ range 11.3 to $14.8 \%$, representing TLs 2.4 to 3.5$)$. $\delta^{15} \mathrm{~N}$, upon which these comparisons are based, tends to enrich with latitude (Wada et al. 1987), and Leach's storm-petrels winter near the equator (Cramp \& Simmons 1977, Huntington et al. 1996). Therefore, while we are fairly confident in the direction of the seasonal dietary change reported here, we may be underestimating its magnitude.

Leach's storm-petrel is highly migratory outside of breeding, moving from colonies in eastern Canada in September/October to winter in the tropics (Cramp \& Simmons 1977, Huntington et al. 1996). Migration occurs on both sides of the Atlantic, with some North American birds moving east before going south, evidenced by numbers that far outnumber the European breeding population in the Bay of Biscay region in fall (September to February, with peak numbers in November and December; Hémery \& Jouanin 1988). Birds winter off West Africa (Brown 1979). Migration also occurs south along the West Atlantic passing Bermuda in September to November, with birds common offshore of Brazil in winter (Bourne 1959, Cramp \& Simmons 1977). In the Southern Ocean lower latitude plankton food bases tend to be enriched in both ${ }^{13} \mathrm{C}$ and ${ }^{15} \mathrm{~N}$ relative to higher latitude waters (Wada et al. 1987). The general latitudinal enrichment of $\delta^{13} \mathrm{C}$ (Rau et al. 1982, Goericke \& Fry 1994) has been used to elucidate wintering areas of Southern Ocean seabirds from $\delta^{13} \mathrm{C}$ values in their feathers (Cherel et al. 2000, 2002, Quillfeldt et al. 2005). While a latitudinal $\delta^{13} \mathrm{C}$ gradient from the poles to the equator is present in both hemispheres, values in the northern hemisphere encompass a much smaller range (ca. $2 \%$ in the north vs. $12 \%$ in the south, Rau et al. 1982). Based upon Rau et al. (1982), the ca. $1 \%$ o $\delta^{13} \mathrm{C}$ enrichment we observed in Leach's storm-petrel primaries during moult suggests a $65^{\circ}$ southerly shift, to ca. $10^{\circ} \mathrm{S}$. A major assumption inherent in this analysis, however, is that stable isotope ratios in foodwebs follow uniform patterns over vast areas, in this case the entire North Atlantic Ocean, and we can perhaps safely assume this is unlikely. While the observed $\delta^{13} \mathrm{C}$ feather enrichment is likely consistent with a latitudinal effect, insight into the moulting location seems unachievable at present. Future studies as suggested by Hobson (1999) aimed at isotopically characterizing the wintering areas of northern hemisphere migrant seabirds and shorebirds could advance knowledge of trophic relationships and feeding ecology in winter and help to delineate habitat use by seabirds outside the reproductive season.
We observed annual differences in patterns of $\delta^{13} \mathrm{C}$ among primary feathers (Table 1, Fig. 1) that suggests variation in the timing of migration and/or the moult location between years. During the 2000/2001 interbreeding period, there was a clear decline in $\delta^{15} \mathrm{~N}$ and TL between early (P1) and mid-moult (P4 and P7), but $\delta^{13} \mathrm{C}$ values were relatively stable, suggesting that all feathers may have been grown at a similar latitude. The $0.5 \% \delta^{13} \mathrm{C}$ enrichment from mid- to late moult (P10) suggests that birds moved before renewing the final primary. Alternatively, during the 2001/02 moult, $\delta^{13} \mathrm{C}$ values in all primaries were relatively enriched (by 0.7 to $1.0 \%$ ) and not dissimilar to those in P10 the previous year. In this year it seems that birds may have renewed all primary feathers closer to the equator.

\section{CONCLUSION}

For seabirds, analyzing stable isotope values in feathers grown away from the breeding site is emerging as a powerful method of investigating feeding ecology, trophic relationships and habitat use during winter. Not only are these studies of intrinsic interest for year-round ecology, but providing information about marine bird wintering areas could shed light on both natural (Bertram et al. 2005, Harris et al. 2005) and anthropogenic factors (Wiese et al. 2001, Montevecchi 2002) affecting their survival. Studies aimed at isotopically characterizing wintering areas of northern hemisphere migrant seabird and shorebird species could significantly improve the understanding of winter ecology. Chemical analyses are an efficient way to study the ecology of small species such as Leach's stormpetrels that are unable to carry the currently available archival and telemetric devices.

Acknowledgements. We are grateful to M. Logan for donating the storm-petrel carcasses, C. Burke for help collecting food samples in the field and M. Quinlan for processing them in the lab. D. MacKinnon and G. Stenson at Fisheries and Oceans Canada in St. John's provided access to otoliths that made fish identifications possible. Special thanks to M. King for preparing the feather and food samples for isotopic analysis. We are also grateful to the Newfoundland and Labrador Parks Division for granting a research access permit to the Baccalieu Island Seabird Ecological Reserve. Discussions with K. Hobson regarding analyses and constructive comments of anonymous reviewers helped improve this manuscript. This research was funded by an NSERC Operating Grant to W.A.M and an NSERC Post-Doctoral Fellowship to A.H.

\section{LITERATURE CITED}

Ainley DG, Lewis TJ, Morrell S (1976) Molt in Leach's and ashy storm-petrels. Wilson Bull 88:76-95

Bertram DF, Harfenist A, Smith BD (2005) Ocean climate and 
El Niño impacts on survival of Cassin's auklet from upwelling and downwelling domains of British Columbia. Can J Fish Aquat Sci 62:2841-2853

Bigelow HB (1926) Plankton of the offshore waters of the Gulf of Maine. Bull US Bur Fish 40:1-509

Bourne WRP (1959) Notes on sea reports received 1958-1959. Sea Swallow 12:6-17

Brown RGB (1979) Seabirds of the Senegal upwelling and adjacent waters. Ibis 121:283-292

Brown RGB (1986) Revised atlas of eastern Canadian seabirds. Bedford Institute of Oceanography, Dartmouth

Campana SE (2004) Photographic atlas of fish otoliths of the Northwest Atlantic. Can Spec Publ Fish Aquat Sci 133: $1-284$

Cherel Y, Hobson KA, Weimerskirch H (2000) Using stableisotope analysis of feathers to distinguish moulting and breeding origins of seabirds. Oecologia 122:155-162

Cherel Y, Bocher P, De Broyer C, Hobson KA (2002) Food and feeding ecology of the sympatric thin-billed Pachyptila belcheri and Antarctic P. desolata prions at Iles Kerguelen, Southern Indian Ocean. Mar Ecol Prog Ser 228:263-281

Cherel Y, Hobson KA, Hassani S (2005) Isotopic discrimination between food and blood and feathers of captive penguins: implications for dietary studies in the wild. Physiol Biochem Zool 78:106-115

Connan M, Mayzaud P, Boutoute M, Weimerskirch $H$, Cherel Y (2005) Lipid composition of stomach oil in a procellariiform seabird Puffinus tenuirostris: implications for food web studies. Mar Ecol Prog Ser 290:277-290

Cramp S, Simmons KEL (eds) (1977) The handbook of the birds of Europe, the Middle East and North Africa: the birds of the western Palearctic, Vol 1. Oxford University Press, Oxford

Croxall JP, Silk JRD, Phillips RA, Afanasyev V, Briggs DR (2005) Global circumnavigations: tracking year-round ranges of nonbreeding albatrosses. Science 5707:249-250

Dahl E (1959) The hyperiid amphipod, Hyperia galba, a true ecto-parasite on jelly-fish. Universitet i Bergen, Årbok 1959. Naturvidenskapelig Rekke 9:1-8

Davoren GK, Burger AE (1999) Differences in prey selection and behaviour during self-feeding and chick provisioning in rhinoceros auklets. Anim Behav 58:853-863

Dittrich B (1988) Studies on the life cycle and reproduction of the parasitic amphipod Hyperia galba in the North Sea. Helgol Wiss Meeresunters 42:79-98

Dunbar MJ (1963) Fiches d'Identification du Zooplancton No. 103. Counseil International pour l'Explorations de la Mer, Copenhagen

Frost N (1936) Amphipoda from Newfoundland waters with a description of a new species. Nfld Dept Nat Res, Div Fish Res Rep Faun Ser 1:1-10

Fry B (1988) Food web structure on Georges Bank from stable C, N and S isotopic compositions. Limnol Oceanogr 33: $1182-1190$

Garthe S, Montevecchi WA, Chapdelaine G, Rail JF, Hedd A (2006) Contrasting foraging tactics of seabirds breeding in different oceanographic domains. Mar Biol (in press)

Goericke R, Fry B (1994) Variations of marine plankton $\delta^{13} \mathrm{C}$ with latitude, temperature, and dissolved $\mathrm{CO}_{2}$ in the world ocean. Global Biogeochem Cycles 8:85-90

Gonzales-Solis J, Croxall JP, Wood AG (2000) Foraging partitioning between giant petrels Macronectes spp. and its relationship with breeding population changes at Bird Island, South Georgia. Mar Ecol Prog Ser 204:279-288

Gonzales-Solis J, Croxall JP, Briggs DR (2002) Activity patterns of giant petrels, Macronectes spp., using different foraging strategies. Mar Biol 140:197-204
Härkönen T (1986) Guide to the otoliths of the bony fishes of the northeast Atlantic. Danbiu ApS, Copenhagen

Harris MP, Anker-Nilssen T, McCleery RH, Erikstad KE, Shaw DN, Grosbois V (2005) Effect of wintering area and climate on the survival of adult Atlantic puffins Fratercula arctica in the eastern Atlantic. Mar Ecol Prog Ser 297: 283-296

Hémery G, Jouanin C (1988) Statut et orgine géographique des populations de pétrel culblanc (Oceanodroma leucorhoa leucorhoa) présentes dans le Golfe de Gascogne. Alauda 56:238-245

Hobson KA (1993) Trophic relationships among high Arctic seabirds: insights from tissue-dependent stable-isotope models. Mar Ecol Prog Ser 95:7-18

Hobson KA (1999) Tracing origins and migration of wildlife using stable isotopes: a review. Oecologia 120:314-326

Hobson KA, Welch HE (1992) Determination of trophic relationships within a high Arctic marine food web using $\delta^{13} \mathrm{C}$ and $\delta^{15} \mathrm{~N}$ analysis. Mar Ecol Prog Ser 84:9-18

Hobson KA, Piatt JF, Pitocchelli J (1994) Using stable isotopes to determine seabird trophic relationships. J Anim Ecol 63: $786-798$

Hodum PJ, Hobson KA (2000) Trophic relationships among Antarctic fulmarine petrels: insights into dietary overlap and chick provisioning strategies inferred from stableisotope $\left(\delta^{15} \mathrm{~N}\right.$ and $\left.\delta^{13} \mathrm{C}\right)$ analyses. Mar Ecol Prog Ser 198: $273-281$

Huntington CE, Butler RG, Mauck RA (1996) Leach's stormpetrel. In: Poole A, Gill F (eds) The birds of North America, No 233. The Academy of Natural Sciences, Philadelphia, PA, and the American Ornithologists' Union, Washington, DC

Linton A (1978) The food and feeding habits of Leach's stormpetrels (Oceanodroma leucorhoa) at Pearl Island, Nova Scotia and Middle Lawn Island, Newfoundland. MSc thesis, Dalhousie University, Halifax

McKelvie DS (1985) The mesopelagic fish fauna of the Newfoundland Basin. Can J Zool 63:2176-2182

Mizutani H, Fukuda M, Kabaya Y (1992) ${ }^{13} \mathrm{C}$ and ${ }^{15} \mathrm{~N}$ enrichment factors of feathers of 11 species of adult birds. Ecology 73:1391-1395

Montevecchi WA (2002) Interactions between fisheries and seabirds. In: Schreiber EA, Burger J (eds) Biology of marine birds. CRC Press, Boca Raton, FL, p 527-557

Montevecchi WA, Birt-Friesen VL, Cairns DK (1992) Reproductive energetics and prey harvest of Leach's stormpetrels in the Northwest Atlantic. Ecology 73:823-832

Nafpaktitis BG, Backus RH, Craddock JE, Haedrich RL, Robinson BH (1977) Family Myctophidae. Mem Sears Found Mar Res 1(7):13-258

Olsson O, North AW (1997) Diet of the king penguin Aptenodytes patagonicus duringthree summers at South Georgia. Ibis 139:504-512

Phillips DL, Gregg JW (2001) Uncertainty in source partitioning using stable isotopes. Oecologia 127:171-179

Quillfeldt P, McGill RAR, Furness RW (2005) Diet and foraging areas of Southern Ocean seabirds and their prey inferred from stable isotopes: review and case study of Wilson's storm-petrel. Mar Ecol Prog Ser 295:295-304

Rau GH, Sweeney RE, Kaplan IR (1982) Plankton ${ }^{13} \mathrm{C}:{ }^{12} \mathrm{C}$ ratio changes with latitude: differences between northern and southern oceans. Deep-Sea Res 29(8A): 1035-1039

Scott WB, Scott MG (1988) Atlantic fishes of Canada. Can Bull Fish Aquat Sci 219

Sherwood GD, Rose GA (2005) Stable isotope analysis of some representative fish and invertebrates of the New- 
foundland and Labrador continental shelf food web. Estuar Coast Shelf Sci 63:537-549

Shih CT (1977) A guide to the jellyfish of Canadian Atlantic waters. National Museum of Natural Sciences. Natural History Series No. 5. National Museums of Canada, Ottawa

Sklepkovych B, Montevecchi WA (1989) The world's largest known nesting colony of Leach's storm-petrels on Baccalieu Island, Newfoundland. American Birds 43:38-42

Thompson DR, Phillips RA, Stewart FM, Waldron S (2000) Low $\delta^{13} \mathrm{C}$ signatures in pelagic seabirds: lipid ingestion as a potential source of ${ }^{13} \mathrm{C}$-depleted carbon in the Procellariiformes. Mar Ecol Prog Ser 208:265-271

Vermeer K, Devito K (1988) The importance of Paracallisoma coecus and myctophid fishes to nesting fork-tailed and Leach's storm-petrels in the Queen Charlotte Islands, British Columbia. J Plankton Res 10:63-75

Wada E, Terazaki M, Kabaya Y, Nemoto T (1987) ${ }^{15} \mathrm{~N}$ and ${ }^{13} \mathrm{C}$ abundances in the Antarctic Ocean with emphasis on the biogeochemical structure of the food web. Deep-Sea Res 34:829-841

Watanuki Y (1985) Food of breeding Leach's storm-petrels (Oceanodroma leucorhoa). Auk 102:884-886

Weimerskirch H, Cherel Y (1998) Feeding ecology of short-

Editorial responsibility: Howard I. Browman (Associate

Editor-in-Chief), Storebø, Norway tailed shearwaters: breeding in Tasmania and foraging in the Antarctic? Mar Ecol Prog Ser 167:261-274

Weimerskirch H, Salamolard M, Sarrazin F, Jouventin P (1993) Foraging strategy of wandering albatrosses through the breeding season: a study using satellite telemetry. Auk 110:325-342

Weimerskirch H, Chastel O, Ackermann L, Chaurand T, Cuenot-Chaillet F, Hindermeyer X, Judas J (1994) Alternate long and short foraging trips in pelagic seabird parents. Anim Behav 47:472-476

Weimerskirch H, Cherel Y, Cuenot-Chaillet F, Ridoux V (1997) Alternative foraging strategies and resource allocation by male and female wandering albatrosses. Ecology 78:2051-2063

Weimerskirch H, Bonadonna F, Bailleul F, Mabille G, Dell'Omo G, Lipp HP (2002) GPS tracking of foraging albatrosses. Science 295:1259

Wiese FK, Montevecchi WA, Davoren GK, Huettmann F, Diamond AW, Linke J (2001) Seabirds at risk around offshore oil platforms in the northwest Atlantic. Mar Pollut Bull 42: $1285-1290$

Winters GH (1989) Life history parameters of sand lances (Ammodytes spp.) from the coastal waters of eastern Newfoundland. J Northwest Atl Fish Sci 9:5-1

Submitted: December 13, 2005; Accepted: May 12, 2006 Proofs received from author(s): August 29, 2006 